\title{
Arsenate removal from groundwater by air-injected EC with al ball anodes: effects of operational parameters
}

\section{Hava akışlı elektrokoagülasyon reaktörü ile yeraltı sularından arsenik (V) giderimine işletme parametrelerinin etkisi}

\author{
Ayşegül Yağmur GÖREN $1^{*}$ ID , Mehmet Salim ÖNCEL ${ }^{2}$ iD , Mehmet KOBYA ${ }^{3}$ iD \\ ${ }^{1}$ Izmir Institute of Technology, Department of Environmental Engineering, Izmir, Turkey. \\ yagmurgoren@iyte.edu.tr \\ 2,3Gebze Technical University, Department of Environmental Engineering, Gebze, Turkey. \\ soncel@gtu.edu.tr, kobya@gtu.edu.tr
}

\begin{abstract}
Treatment of arsenate from groundwater by electrocoagulation (EC) reactor with air supply unit using Al ball electrodes were studied in this paper. Influence of some operating variables, for instance, applied current (0.075-0.3 A), initial $\mathrm{pH}$ (5.5-8.5), air flow rate $(0-6 \mathrm{~L} / \mathrm{min})$, size of Al ball electrodes (5-10 $\mathrm{mm})$, and height of electrode in $E C$ reactor $(2-8 \mathrm{~cm})$ on the As(V) removal efficiency were evaluated. The As (V) removal efficiency increased with the increment of applied current, air flow, electrode altitude in EC reactor, and EC time while its removal efficiency decreased with the increment of size of Al ball electrodes. The maximum $A s(V)$ removal percentage, minimum operating cost and energy consumption were found as $98.68 \%, 0.609 \$ / m^{3}$ and $3.7694 \mathrm{kWh} / \mathrm{m}^{3}$ at $\mathrm{pH}$ of 7.5, current density of $0.30 \mathrm{~A}$, size of Al balls of $7.5 \mathrm{~mm}$, height of electrode in $E C$ of $5 \mathrm{c}^{\dagger} \mathrm{m}$, and air flow rate of $6 \mathrm{~L} / \mathrm{min}$, respectively.
\end{abstract}

Keywords: Air-injected EC reactor, Al ball electrodes, As(V).

\section{Introduction}

Groundwater contaminated with arsenic became a major concern around the worldwide especially in undeveloped or developing countries. Arsenic contamination has been reported from a several countries in the world for instance, Argentina, Cambodia, Chile, Finland, Hungary, India, Japan, Nepal, Turkey, United States, and Vietnam [1]-[3].Turkey is also one of the countries under threat of the arsenic pollution. Especially in the western parts of the country, water sources contain higher levels of arsenic than the maximum contaminated level (MCL) set as $10 \mu \mathrm{g}$ As/L which are as follows: 7.1-834 $\mu \mathrm{g} / \mathrm{L}$ for Kütahya, $10-10,700 \mu \mathrm{g} / \mathrm{L}$ in surface and ground waters of Igdekoy near the Hisarcik colemanite mining open pits, 30-911 $\mu \mathrm{g} / \mathrm{L}$ for Balikesir in located near boron mines open pits, 10.3$201 \mu \mathrm{g} / \mathrm{L}$ for Aksaray, 1-170 $\mu \mathrm{g} / \mathrm{L}$ for Izmir, 50-120 $\mu \mathrm{g} / \mathrm{L}$ for Giresun, 0.5-345 $\mu \mathrm{g} / \mathrm{L}$ for Sivas, respectively [4]-[10]. Exposure to arsenic lead chronic health problems including pigmentation changes, hyperkeratosis, and cancers of bladder, kidney, liver, skin, lung, and prostate [11]-[12]. Therefore, the WHO and the US-EPA have established $10 \mu \mathrm{g}$ As/L as a guideline value for arsenic contaminant level in drinking water [13]-[14].

\begin{abstract}
Öz Bu çalıșmada hava akıșli elektrokoagülasyon (HA-EK) reaktörü kullanılarak yeraltı sularından arsenik (V) giderimi çalışıllmıştır. Arsenik (V) giderimi üzerine, uygulana akım (0.075-0.3 A), başlangıç pH'sı (5.5-8.5), hava akıs debisi (0-6 L/dk.), Al bilye elektrot boyutu (5-10 $\mathrm{mm}$ ) ve EK reaktöründe elektrot yüksekliği $(2-8 \mathrm{~cm})$ gibi işletme parametrelerinin etkisi incelenmiștir. Arsenik giderimi veriminde artan akım yoğunluğu, hava debisi ve elektrot yüksekliği ile birlikte ciddi bir artıș gözlenmiștir. Ancak, arsenik giderim verimi artan Al bilye boyutu ile birlikte azalmıștır. Optimum șartlarda (pH:7.5 akım yoğunluğu: $0.3 \mathrm{~A}$, Al bilye boyutu: $7.5 \mathrm{~mm}$, elektrot yüksekliği: $5 \mathrm{~cm}$, hava akış debisi: $6 \mathrm{~L} / \mathrm{dk}$.) en yüksek arsenik giderim verimi \%98.68, en düsük işletme maliyeti $0.609 \$ / \mathrm{m}^{3}$ ve en düşük enerji tüketimi $3.7694 \mathrm{kWh} / \mathrm{m}^{3}$ olarak hesaplanmiștır.
\end{abstract}

Anahtar kelimeler: HA-EK reaktörü, Al bilye elektrotlar, As(V).
Number of treatment processes have been conducted to remove arsenic in the wastewater/drinking water. These technologies can be listed as follows: adsorption, precipitation, oxidation-filtration, ion exchange, membrane process such as reverse osmosis, biological process [15]-[19]. However, these treatment technologies required several $\mathrm{pH}$ adjustments, high maintenance and operating costs, need a long operating time, and generate a large amount of sludge and secondary pollutants. Therefore, the alternative treatment methods were needed to overcome or/and enhance some of these problems. Electrocoagulation (EC) technique has been receiving greater attention for the removal of arsenic due to its compact treatment facility, affordable maintenance and operating cost, high treatment performance, low sludge formation, and no addition of reagents for oxidation of arsenite (As(III)) to arsenate $(\mathrm{As}(\mathrm{V}))$ [20]-[22]. In EC process, rod and plate $\mathrm{Al}$ or $\mathrm{Fe}$ electrodes commonly used for arsenic removal [23]-[24]. However, these types of electrodes have some disadvantages because of low surface areas and difficulties of operation. Thus, EC reactor using Fe ball type anodes for removal of arsenic was designed and optimized for investigating the operating variables to eliminate the above problems in our previous work [25].

\footnotetext{
${ }^{*}$ Corresponding author/Yazıșılan Yazar
} 
In this study, As (V) removal from groundwater by EC reactor with air injection unit using $\mathrm{Al}$ ball anodes was investigated to evaluate the optimum operating variables. Therefore, influence of operating parameters such as applied current, initial $\mathrm{pH}, \mathrm{EC}$ time, air flow rate, size of Al ball electrodes, and electrode level in the EC reactor. The amount of sludge formation, operating cost, energy and electrode consumptions were also evaluated.

\section{Materials and method}

\subsection{Groundwater Characterization}

The groundwater used in EC process (silica $10.18 \mathrm{mg} / \mathrm{L}$, sulphate $94.2 \mathrm{mg} / \mathrm{L}$, nitrate $24.0 \mathrm{mg} / \mathrm{L}$, manganese $0.006 \mathrm{mg} / \mathrm{L}$, total hardness $418 \mathrm{mg} \mathrm{CaCO} / / \mathrm{L}$, total alkalinity $260 \mathrm{mg}$ $\mathrm{CaCO}_{3} / \mathrm{L}$, dissolved organic carbon $5 \mathrm{mg} / \mathrm{L}$, $\mathrm{pH} 7$, conductivity $1055 \mu \mathrm{S} / \mathrm{cm}$, and arsenic, aluminum, phosphate, fluoride, iron ions were not detected) was collected from the province of Kocaeli, Turkey. The concentration of ions were measured by IC (Shimadzu HIC-20A) and ICP-OES (Perkin Elmer ICP-OES Optima 7000 DV), respectively. A groundwater containing specified arsenate concentration $(200 \mu \mathrm{g} / \mathrm{L})$ was prepared freshly dissolving sodium arsenate salt $\left(\mathrm{Na}_{2} \mathrm{HAsO}_{4} \times 7 \mathrm{H}_{2} \mathrm{O}\right)$ to simulate arsenic contaminated groundwater. The arsenate concentration of samples was measured by ICP-OES. $\mathrm{pH}$ of the groundwater samples was set by $0.1 \mathrm{M} \mathrm{H}_{2} \mathrm{SO}_{4}$ and $0.1 \mathrm{M} \mathrm{NaOH}$.

\subsection{EC reactor set-up and procedure}

Figure 1. shows a diagram of the air-injected EC reactor. A detailed design of the air-injected EC reactor is described in our previous study [25]. At the beginning of each experimental run, the air-injected EC reactor was fed with $0.8 \mathrm{~L}$ of the groundwater. All experiments were conducted in a batch mode and effect of operating conditions on arsenate removal such as operating time, $\mathrm{pH}$, current density, air flow rate, column height in reactor, and $\mathrm{Al}$ ball size were investigated. During the experiments, current density applied using DC power supply and voltage values were recorded to calculate the energy consumptions. The weight of $\mathrm{Al}$ ball electrodes were also measured before and after the experiments to calculate the electrode consumption. The samples were collected at specified time intervals and filtered using $0.45 \mu \mathrm{m}$ filter before analyses.

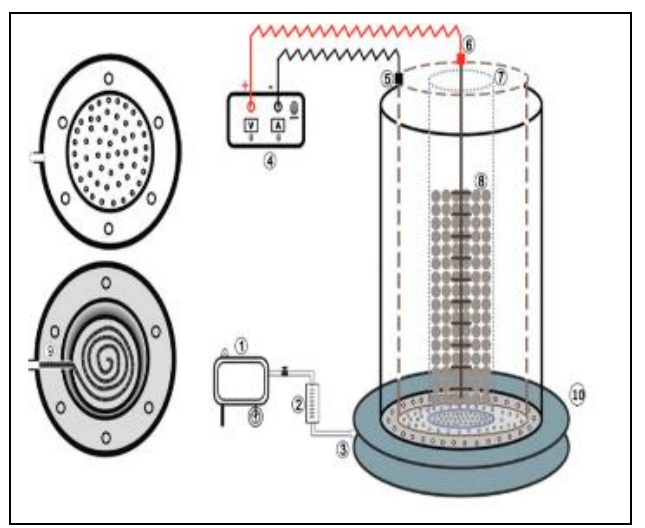

Figure1. The diagram of air-injected EC reactor. (1): Air supplier, (2): Flow meter, (3): Pipe line for air supply, (4): Power source, (5): Cathode, (6): Steel rod, (7): Cylindrical shaped Plexiglas, (8): All ball electrodes, (9): Air diffuser [25].

\section{Results and discussion}

The EC process can be affected by number of operating variables, as follows, applied current, $\mathrm{pH}$, EC time, air flow rate, size of Al ball electrodes, and electrode height in the EC reactor. As shown in Table 1, the low, middle, and high values of operating parameters were specified based on our previous work [25].

Table 1. Operating parameters and levels.

\begin{tabular}{ccccc}
\hline Operating & Unit & \multicolumn{3}{c}{ Levels } \\
\cline { 3 - 5 } Parameters & & Low & Middle & High \\
\hline Initial pH & - & 5.5 & $6.5-7.5$ & 8.5 \\
Current density & $\mathrm{A}$ & 0.075 & 0.15 & 0.30 \\
Air flow & L/min & 0 & 2 & 6 \\
Size of electrode & $\mathrm{mm}$ & 5 & 7.5 & 10 \\
Electrode height & $\mathrm{cm}$ & 2 & 5 & 8 \\
\hline
\end{tabular}

\subsection{Effect of applied current}

In EC process, EC time and current are the most important operating variables which are controlling the system efficiency. Applied current affects the amount of coagulant and mixing rate of the solution in EC reactor [26]-[28]. Figure 2. demonstrates the effect of current density on residual As (V) concentration during the EC time of $18 \mathrm{~min}$. During the experiments, the initial $\mathrm{pH}$, electrode height in $\mathrm{EC}$ reactor, air flow rate, and size of $\mathrm{Al}$ ball anodes, selected as 7.5, $5.0 \mathrm{~cm}, 6 \mathrm{~L} / \mathrm{min}$, and $7.5 \mathrm{~mm}$, respectively. In Figure 2, the EC time necessary to meet limit of $<10 \mu \mathrm{g} / \mathrm{L}$ of WHO limit arsenic concentration decreased with increasing applied current due to the efficiency of $\mathrm{OH}$ - ions production at cathode and dissolution of $\mathrm{Al}^{3+}$ ions at anode increased. The observed effluent As (V) concentrations for applied currents of $0.075,0.15$, and $0.3 \mathrm{~A}$ were $11.02 \mu \mathrm{g} / \mathrm{L}$, $7.42 \mu \mathrm{g} / \mathrm{L}$, and $2.6 \mu \mathrm{g} / \mathrm{L}$ at operating time of $18 \mathrm{~min}$. It can be also concluded that the residual $\mathrm{As}(\mathrm{V})$ concentration at $0.075 \mathrm{~A}$ was not lower than $10 \mu \mathrm{g} / \mathrm{L}$ for EC time of $18 \mathrm{~min}$, while it took almost $14 \mathrm{~min}$ at $0.150 \mathrm{~A}$ and $10.5 \mathrm{~min}$ at $0.3 \mathrm{~A}$ to reached limit arsenic concentration of $10 \mu \mathrm{g} / \mathrm{L}$. The EC time for As (V) removal was reduced from $18 \mathrm{~min}$ to $10.5 \mathrm{~min}$ with the increment of applied current from $0.075 \mathrm{~A}$ to $0.3 \mathrm{~A}$.

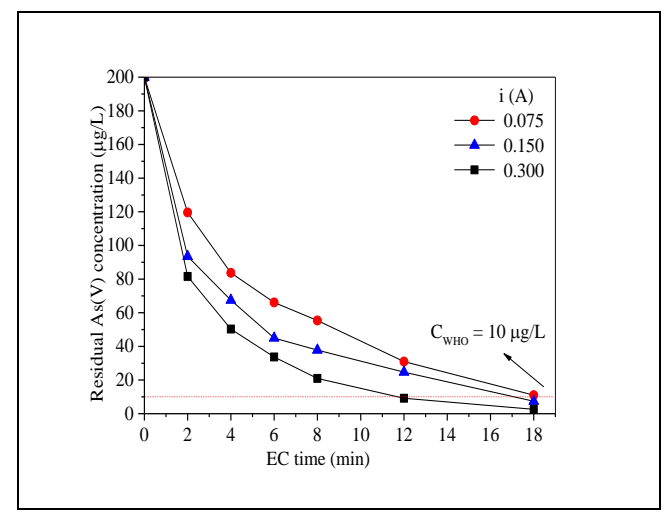

Figure 2. Effect of applied current on residual As (V).

Based on the Faraday's law, consumption of the anode material is directly correlated with the charge loading. The production of coagulant to remove arsenic increases when the charge loading was increased. Therefore, charge loading is another important parameter which controls the reactions in EC reactor. Charge loading was calculated with equation represented as below:

$$
q\left(F / m^{3}\right)=\frac{i \times t_{E C}}{F \times v}
$$

where $\mathrm{q}$ is the charge loading $\left(\mathrm{F} / \mathrm{m}^{3}\right.$ water $), \mathrm{t}_{\mathrm{EC}}$ is the $\mathrm{EC}$ time ( $\mathrm{min}$ ), $\mathrm{F}$ is the Faraday's constant ( 96487 Coulomb), and $\mathrm{v}$ is the solution volume $\left(\mathrm{m}^{3}\right)$ in EC reactor. The high amount of 
aluminum hydroxide flocs forms with the high charge loadings as it increases $\mathrm{Al}^{2+}$ ions in solution. Also, the operating cost of EC process increased with the increment of charge loading. Hence, the charge loading needed to be optimized to minimize the operating cost. The charge loading required to reach $<10$ $\mu \mathrm{g} / \mathrm{L}$ limit value were $1.1993 \mathrm{~F} / \mathrm{m}^{3}$ at $0.075 \mathrm{~A}, 2.3986 \mathrm{~F} / \mathrm{m}^{3}$ at $0.15 \mathrm{~A}$, and $4.7971 \mathrm{~F} / \mathrm{m}^{3}$ at $0.3 \mathrm{~A}$ in EC time of $18 \mathrm{~min}$. The operating cost of the treated water were also determined by considering the amounts of electrode consumption (ELC) and energy consumption (ENC) in the EC process. Based on the Turkish suppliers in March 2018, charges for Al ball electrodes $(\beta)$ and electrical energy $(\alpha)$ were $15 \$ / \mathrm{kg}$ and $0.19 \$ / \mathrm{kWh}$, respectively. The operating cost (OC) of the EC reactor was determined as shown in equation:

$$
O C\left(\$ / m^{3}\right)=(\alpha \times E N C)+(\beta+E L C)
$$

The ENC and ELC was also calculated with the following equations:

$$
\begin{aligned}
& E N C\left(k W h / m^{3}\right)=\frac{i \times t_{E C} \times U}{v} \\
& E L C\left(k g / m^{3}\right)=\frac{i \times t_{E C} \times M_{A l}}{z_{A l} \times F \times v}
\end{aligned}
$$

where $\mathrm{U}$ is the cell voltage $(\mathrm{V}), \mathrm{M}_{\mathrm{Al}}$ is the molecular weight of the $\mathrm{Al}$ ball anode $\left(\mathrm{M}_{\mathrm{Al}}: 26.98 \mathrm{~g} / \mathrm{mol}\right)$, and $\mathrm{z}_{\mathrm{Al}}$ is the electron number in oxidation/reduction reactions ( $\mathrm{z}_{\mathrm{Al}}$ : 3). The operating costs, electrode and energy consumptions calculated from equations (2), (3), and (4) were $0.350,0389$, and $0.458 \$ / \mathrm{m}^{3}$ $0.0055,0.0114$, and $0.0347 \mathrm{~kg} / \mathrm{m}^{3}-0.3153,0.9360$ and 2.7060 $\mathrm{kWh} / \mathrm{m}^{3}$ at $0.075,0.15$, and $0.3 \mathrm{~A}$, respectively. The sludge production were also determined as $0.096 \mathrm{~kg} / \mathrm{m}^{3}, 0.079 \mathrm{~kg} / \mathrm{m}^{3}$, and $0.147 \mathrm{~kg} / \mathrm{m}^{3}$ for the currents of $0.075,0.15$, and $0.3 \mathrm{~A}$. In conclusion, the results indicated removal efficiency of arsenate increased with the increment of applied current. Thus, the optimum applied current for effective arsenate removal were selected as $0.3 \mathrm{~A}$ for the rest of experiments.

\section{$3.2 \quad$ Effect of solution $\mathbf{p H}$}

The solution $\mathrm{pH}$ has great impact on removal of arsenate in aqueous solutions and performance of EC process [23].The negatively charged dominant $\mathrm{As}(\mathrm{V})$ species in the aqueous solution are $\mathrm{AsO}_{4}{ }^{3-}$ at $\mathrm{pH}>12.4, \mathrm{H}_{2} \mathrm{AsO}_{4}^{-}$at $3.6<\mathrm{pH} \mathrm{7.2,} \mathrm{and}$ $\mathrm{HAsO}_{4}{ }^{2-}$ at $7.2<\mathrm{pH}<12.4$. According to the literature, the adsorption of As (V) on amorphous $\mathrm{AlOH}_{3(\mathrm{~s})}$ at $\mathrm{As}(\mathrm{V})$ concentration of $1600 \mathrm{mg} / \mathrm{L}$ and $7492 \mu \mathrm{g} / \mathrm{g}$ were observed as $>100 \mathrm{mg} / \mathrm{g}$, and $118.9 \mu \mathrm{g} / \mathrm{g}$ at $\mathrm{pH} 6$, respectively [29]. In the case of EC reactor using $\mathrm{Al}$ electrodes, $\mathrm{Al}^{3+}$ ions dissolved from the anode and react with the hydroxyl ions dissolved from the cathode to form aluminum hydroxide $\left(\mathrm{AlOH}_{3(\mathrm{~s})}\right)$. The main anode, cathode, and As (V) removal mechanisms were represented with the following equations:

Anode reaction:

$$
A l_{(s)} \rightarrow A l^{3+}+3 e^{-}
$$

Cathode reaction:

$$
3 \mathrm{H}_{2} \mathrm{O}+3 e^{-} \rightarrow 3 / 2 \mathrm{H}_{2(g)}+3 \mathrm{OH}^{-}
$$

Adsorption reactions:

$$
\mathrm{Al}(\mathrm{OH})_{3(\mathrm{~s})}+\mathrm{H}_{2} \mathrm{AsO}_{4}^{-} \rightarrow\left[\mathrm{Al}(\mathrm{OH})_{3(s)} * \mathrm{H}_{2} \mathrm{AsO}_{4}^{-}\right]
$$

$$
\mathrm{Al}(\mathrm{OH})_{3(s)}+\mathrm{HAsO}_{4}^{2-} \rightarrow\left[\mathrm{Al}(\mathrm{OH})_{3(s)} * \mathrm{HAsO}_{4}^{2-}\right]
$$

Co-precipitation reaction:

$$
\begin{aligned}
x \mathrm{Al}^{3+}+(\mathrm{z}) \mathrm{OH}^{-} & +y \mathrm{HAsO}_{4}^{2-} \\
& \rightarrow \mathrm{Al}_{x}(\mathrm{OH})_{(\mathrm{z})}-\left(\mathrm{HAsO}_{4}\right)_{y(s)}
\end{aligned}
$$

In this study to examine the $\mathrm{pH}$ effect on arsenate removal by the EC, experiments was carried out at $\mathrm{pH}$ of 5.5-8.5 since most of groundwater have the $\mathrm{pH}$ range of 6-9 [23]. As shown in Figure 3. As (V) removal percentages and residual concentrations $(<10 \mu \mathrm{g} / \mathrm{L})$ were found as $99.20 \%$ and 8.02 $\mu \mathrm{g} / \mathrm{L}$ at $12 \mathrm{~min}$ for $\mathrm{pH} 5.5,96.22 \%$ and $9.65 \mu \mathrm{g} / \mathrm{L}$ at $12 \mathrm{~min}$ for $\mathrm{pH} 6.5,95.65 \%$ and $9.20 \mu \mathrm{g} / \mathrm{L}$ at $12 \mathrm{~min}$ for $\mathrm{pH} 7.5$, and $92.01 \%$ and $7.9 \mu \mathrm{g} / \mathrm{L}$ at $18 \mathrm{~min}$ for $\mathrm{pH} 8.5$, respectively. According to results, the air-injected EC reactor was remove As (V) efficiently at $\mathrm{pH}$ 5.5-8.5. However, the increase of removal efficiency was slight at $\mathrm{pH} 7.5-8.5$, while the removal was significant at $\mathrm{pH}$ 5.5-7.5. Since the $\mathrm{Al}^{3+}$ and $\mathrm{OH}^{-}$react to form monomeric and polymeric $\mathrm{Al}(\mathrm{OH})_{\mathrm{x}}$ species at neutral conditions, which have large hydroxyl groups to adsorb arsenic. At neutral conditions, the arsenic removal was dominated by adsorption and precipitation while at basic $\mathrm{pH}$ conditions the removal was only dominated by precipitation. Hence, the arsenate removal efficiencies using $\mathrm{Al}$ ball electrodes were better at neutral $\mathrm{pH}$ (7.5).

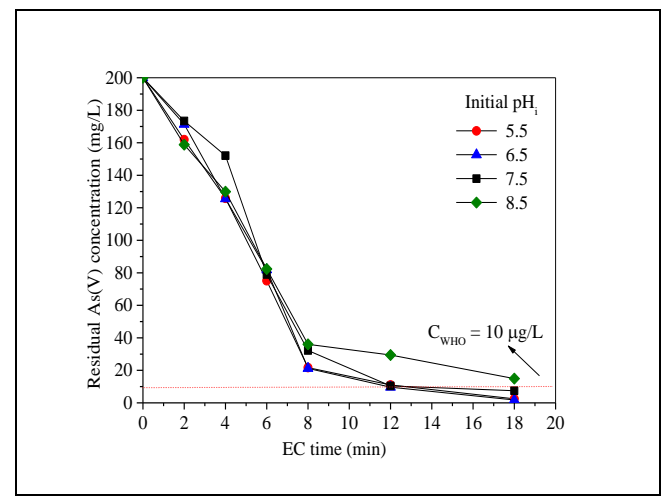

Figure 3. Effect of initial $\mathrm{pH}$ on residual As (V).

Values of electrode and energy consumptions, operating cost, and amount of sludge formation were also calculated as 0.0318 $\mathrm{kg} / \mathrm{m}^{3}$ and $2.8941 \mathrm{kWh} / \mathrm{m}^{3}-0.718 \$ / \mathrm{m}^{3}-0.2825 \mathrm{~kg} / \mathrm{m}^{3}$ for $\mathrm{pH}$ $5.5, \quad 0.0221 \mathrm{~kg} / \mathrm{m}^{3}$ and $3.2027 \mathrm{kWh} / \mathrm{m}^{3}-0.726 \quad \$ / \mathrm{m}^{3}$ $-0.2330 \mathrm{~kg} / \mathrm{m}^{3}$ for $\mathrm{pH} 6.5,0.0334 \mathrm{~kg} / \mathrm{m}^{3}$ and $3.3069 \mathrm{kWh} / \mathrm{m}^{3}$ $0.805 \$ / \mathrm{m}^{3}-0.2309 \mathrm{~kg} / \mathrm{m}^{3}$ for $\mathrm{pH} 7.5$, and $0.0225 \mathrm{~kg} / \mathrm{m}^{3}$ and $2.7694 \mathrm{kWh} / \mathrm{m}^{3}-0.645 \$ / \mathrm{m}^{3}-0.1700 \mathrm{~kg} / \mathrm{m}^{3}$ for $\mathrm{pH} 8.5$, respectively. The $\mathrm{pH}$ values after the EC process changed from $5.5,6.5,7.5$ and 8.5 to $6.01,7.0,7.84$ and 8.96 , respectively. This slight increase of $\mathrm{pH}$ values related to the formation of $\mathrm{H}_{2(\mathrm{~g})}$ and $\mathrm{OH}^{-}$ions on cathode which compensated the acid buffer thus form an alkaline solution [30].

\subsection{Effect of electrode level in EC reactor and size of Al ball electrodes}

The electrode height in EC reactor is another important parameter which effects the arsenate removal efficiency and electrode life time. The effect of electrode height in EC reactor was investigated at air flow rate of $6 \mathrm{~L} / \mathrm{min}$, size of Al ball electrodes of $7.5 \mathrm{~mm}$, pH of 7.5 and applied current of $0.3 \mathrm{~A}$. Figure 4. shows the effect of electrode height on residual As (V) concentration. The residual As (V) concentration decreased with the increasing electrode height in EC reactor since 
increase in total $\mathrm{Al}$ anode surface area. The increasing arsenate removal efficiency with the increment of electrode height could be explained by Faraday's Law.



Figure 4. Effect electrode height on residual As (V).

Total $\mathrm{Al}$ anode surface area were $0.032 \mathrm{~m}^{2}, 0.076 \mathrm{~m}^{2}$, and 0.117 $\mathrm{m}^{2}$ for electrode height of $2 \mathrm{~cm}, 5 \mathrm{~cm}$, and $8 \mathrm{~cm}$, respectively. As seen in Figure 4, the residual As (V) concentration and minimum operating time were $1.14 \mu \mathrm{g} / \mathrm{L}$ and $8 \mathrm{~min}$ for $8 \mathrm{~cm}$, $9.07 \mu \mathrm{g} / \mathrm{L}$ and $12 \mathrm{~min}$ for $5 \mathrm{~cm}$, and $10.12 \mu \mathrm{g} / \mathrm{L}$ and $18 \mathrm{~min}$ for electrode height of $2 \mathrm{~cm}$, respectively.

Another important operating condition is the size of Al ball electrodes which influences the residual As (V) concentration. The effect of size of $\mathrm{Al}$ balls on As (V) removal shown in Figure 5. The size of Al ball electrodes in EC rector decreases at a specified electrode height in EC reactor $(8 \mathrm{~cm})$, the surface area of Al ball electrodes used in the EC increases. The residual As (V) concentrations for $5.0 \mathrm{~mm}, 7.5 \mathrm{~mm}$, and $10 \mathrm{~mm} \mathrm{Al}$ electrode sizes were calculated as $3.26 \mu \mathrm{g} / \mathrm{L}, 9.52 \mu \mathrm{g} / \mathrm{L}$, and $11.97 \mu \mathrm{g} / \mathrm{L}$ at EC time of $12 \mathrm{~min}$, respectively. When the surface area of $\mathrm{Al}$ ball electrodes increased, the As (V) removal efficiency increased due to the formation of significantly high amount of $\mathrm{Al}^{3+}$ ions in solution. The optimum size of $\mathrm{Al}$ ball electrodes were selected as $7.5 \mathrm{~mm}$ since there was no difference between $5 \mathrm{~mm}$ and $7.5 \mathrm{~mm}$ of the size of $\mathrm{Al}$ ball electrode size in terms of arsenic removal efficiency. However, the Al ball size of $7.5 \mathrm{~mm}$ was chosen as it has higher surface area.

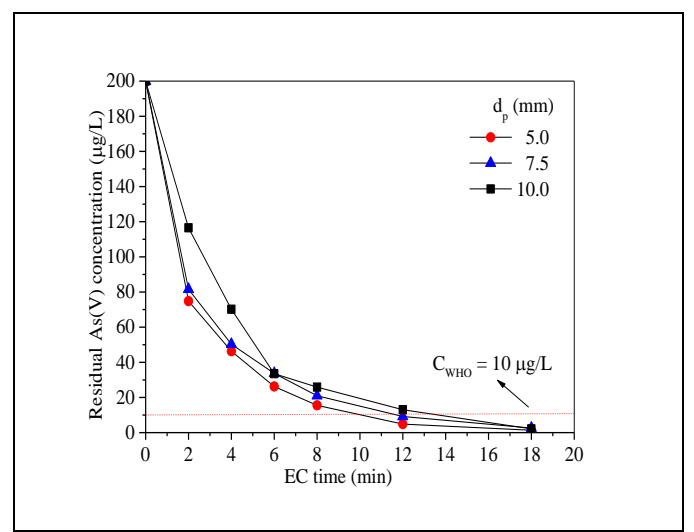

Figure 5. Effect of size of Al ball electrodes on residual As (V).

\subsection{Effect of air/oxygen flow in EC reactor}

The air flow is a notable operating parameter in EC system to provide homogenous mixture in solution. In addition, the air flow also supports the coagulation/flocculation mechanisms as it supply the mixing in the solution in EC reactor. The formation of passivation layer on anode surfaces also prevents with the air flow rate [31].

The effect of air flow on treatment efficiency were investigated at 0,2 , and $6 \mathrm{~L} / \mathrm{min}$ of air flows. The residual As (V) amount diminished with the increasing air flow as seen in Figure 6. The residual $\mathrm{As}(\mathrm{V})$ concentration at $\mathrm{EC}$ time of 12 min were found as $7.06 \mu \mathrm{g} / \mathrm{L}$ for $6 \mathrm{~L} / \mathrm{min}$ while the residual arsenic concentration was not achieved $<10 \mu \mathrm{g} / \mathrm{L}$ limit value for 0 and $2 \mathrm{~L} / \mathrm{min}$ air flows. Also, the residual As (V) concentrations reached $<10 \mu \mathrm{g} / \mathrm{L}$ limit arsenic value at the end of the EC time of $14 \mathrm{~min}$. At EC time of $18 \mathrm{~min}$, the residual As (V) concentrations were $5.51 \mu \mathrm{g} / \mathrm{L}, 2.64 \mu \mathrm{g} / \mathrm{L}$, and $2.58 \mu \mathrm{g} / \mathrm{L}$ for air flow rate of 0,2 , and $6 \mathrm{~L} / \mathrm{min}$, respectively. The operating cost, energy consumption, and charge loading at the end of the EC time of $18 \mathrm{~min}$ were also calculated as $0.913 \$ / \mathrm{m}^{3}$, $3.8867 \mathrm{kWh} / \mathrm{m}^{3}$, and $0.0354 \mathrm{~F} / \mathrm{m}^{3}$ for $0 \mathrm{~L} / \mathrm{min}$, and $0.762 \$ / \mathrm{m}^{3}$, $3.4689 \mathrm{kWh} / \mathrm{m}^{3}$, and $0.0329 \mathrm{~F} / \mathrm{m}^{3}$ for $2 \mathrm{~L} / \mathrm{min}$, and $0.609 \$ / \mathrm{m}^{3}$, $3.7694 \mathrm{kWh} / \mathrm{m}^{3}$, and $0.0195 \mathrm{~F} / \mathrm{m}^{3}$ for $6 \mathrm{~L} / \mathrm{min}$.

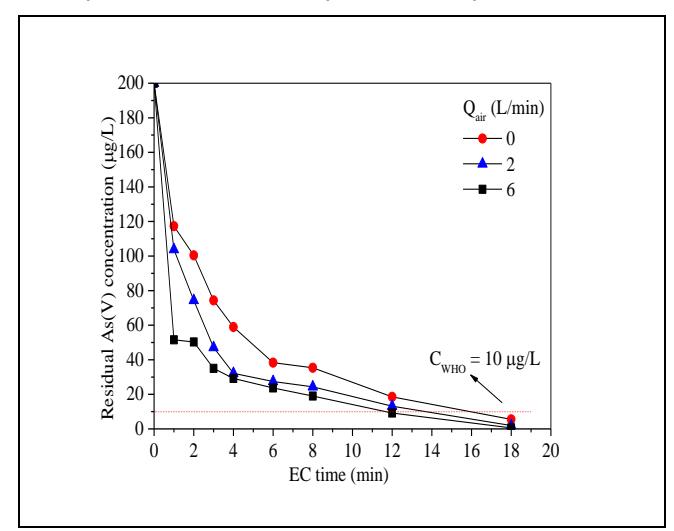

Figure 6. Effect of air/oxygen flow on residual As (V).

Consequently, it can be concluded that the novel air-injected EC reactor significantly increased the removal efficiency of As (V). Since, the homogenous mixing in solution increased with the increasing air flow rate. Also, the passivation layer on the surfaces of Al ball anodes prevented with the increment of air flow rate.

\subsection{Comparison of arsenic removal by EC process}

The removal of arsenic by EC process was studied by many authors. This study compared with the other studies in the literature based on arsenic concentrations, electrode types (Al, $\mathrm{Fe}, \mathrm{Cu}$ and hybrid electrode combinations), and electrode shapes (rod, plate and ball).

The arsenic removal efficiency of EC process for groundwater containing $285 \mu \mathrm{g} / \mathrm{L}$ arsenate achieved a maximum removal efficiency of $96.9 \%$ and $99.3 \%$ using Fe plate and $\mathrm{Fe}$ ball electrodes, respectively [26]. In a separate study, the removal efficiency and operating cost in a batch mode EC were $99.2 \%$ and $0.031 \$ / \mathrm{m} 3$ using Fe ball electrodes at $150 \mu \mathrm{g} \mathrm{As}(\mathrm{V}) / \mathrm{L}[25]$. The authors also observed that the arsenic removal efficiency and energy consumption were found as $92.6 \%$ and 1.19 $\mathrm{kWh} / \mathrm{m} 3$ using Al plate type electrodes [32]. Arsenic removal by EC process carried out using $\mathrm{Al}$ plate at operating time of $62.8 \mathrm{~min}$ and $85 \%$ of arsenic removal efficiency were observed [33]. In our previous work, the comparison of arsenic removal by EC process were reported in more detail [34]. The removal efficiency in the EC process using Al ball electrodes was calculated as $98.68 \%$ which was higher compared to the 
literature values. Also, conventional treatment processes used for the removal of arsenic were presented in the introduction. The EC process compared with the other studies, EC turns out to be an effective and environmentally friendly method for the removal of arsenic from groundwater.

\section{Conclusion}

In this paper, EC reactor was investigated for removal of As (V) and observed to influence of operational variables. The results showed that the increasing applied current, electrode level in EC reactor, EC time, and air flow rate have positive effect on $\mathrm{As}(\mathrm{V})$ treatment efficiency while the increasing size of Al ball electrodes have negative effect on removal efficiency. On the other hand, the effect of initial $\mathrm{pH}$ on As (V) removal was not notable in specified $\mathrm{pH}$ values. According to results, the minimum residual $\mathrm{As}(\mathrm{V})$ and minimum operating cost were found as $2.64 \mu \mathrm{g} / \mathrm{L}$ and $0.609 \$ / \mathrm{m}^{3}$ at initial $\mathrm{pH}$ of 7.5 , applied current of $0.3 \mathrm{~A}$, size of Al balls of $7.5 \mathrm{~mm}$, height of electrode in EC of $5 \mathrm{~cm}$, and air flow rate of $6 \mathrm{~L} / \mathrm{min}$. It was concluded from this work that As (V) could be removed effectively by EC reactor using Al ball electrodes.

\section{Acknowledgement}

The project is financed by kind support of TUBITAK (The Scientific and Technical Research Council of Turkey, Project Number: 111Y103).

\section{References}

[1] Smedley PL, Kinniburgh DG. "A review of the source, behavior and distribution of arsenic in natural waters". Applied Geochemistry, 17(5), 517-568, 2002.

[2] Mukherjee A, Sengupta MK, Hossain MA, Ahamed S, Das B, Nayak B, Lodh D, Rahman MM, Chakraborti D. "Arsenic contamination in groundwater: a global perspective with emphasis on the Asian scenario". Journal of Health, Population Nutrition, 24(2), 142-163, 2006.

[3] Barringer JL, Szabo Z, Wilson TP, Bonin JL, Kratzer T, Cenno K, Romagna T, Alebus M, Hirst B. "Distribution and seasonal dynamics of arsenic in a shallow lake in north western New Jersey, USA". Environmental Geochemistry and Health, 33(1), 1-22, 2011.

[4] Gunduz O, Bakar C, Simsek C, Baba A, Elci A, Gurleyuk H, Mutlu M, Cakir A. "Statistical analysis of causes of death (2005-2010) in villages of Simav Plain, Turkey, with high arsenic levels in drinking water supplies". Archives of Environmental and Occupational Health, 70(1), 35-46, 2015.

[5] Colak M, Gemici U, Tarcan G. "The effects of colemanite deposits on the arsenic concentrations of soil and groundwater in Igdeköy-Emet, Kütahya, Turkey". Water Air and Soil Pollution, 149(3), 127-143, 2003.

[6] Gemici U, Tarcan G, Helvaci C, Somay AM. "High arsenic and boron concentrations in groundwaters related to mining activity in the Bigadiç borate deposits (Western Turkey)". Applied Geochemistry, 23(8), 2462-2476, 2008.

[7] Altaş L, Işik M, Kavurmaci M. "Determination of arsenic levels in the water resources of Aksaray Province, Turkey". Journal of Environment Management, 92(9), 2182-2192, 2011.

[8] Aksoy N, Şimșek C, Gunduz O."Groundwater contamination mechanism in a geothermal field: A case study of Balcova, Turkey". Journal of Contamination Hydrology, 103(1-2), 13-28, 2009.
[9] Karakaya N, Karakaya MÇ, Nalbantçllar MT, Yavuz F. "Relation between spring-water chemistry and hydrothermal alteration in the Saplıca volcanic rocks, Sebinkarahisar (Giresun, Turkey)". Journal of Geochem. Exploriation, 93(1), 35-46, 2007.

[10] Simsek C. "Assessment of naturally occurring arsenic contamination in the groundwater of Sarkisla plain (Sivas-Turkey)". Environmental Earth Sciences, 68(4), 691-702, 2013.

[11] Sharma VK, Sohn M. "Aquatic arsenic: toxicity, speciation, transformations, and remediation". Environmental International, 35(4), 743-759, 2009.

[12] Choong TSY, Chuah TG, Robiah Y, Koay FLG, Azni I. "Arsenic toxicity, health hazards and removal techniques from water: an overview". Desalination, 217(1-3), 139-166, 2007.

[13] WHO (World Health Organisation). "Arsenic in Drinkingwater". World Health Organization, Switzerland-Geneva, (Fact Sheet No. 210), 2001.

USEPA (United States Environmental Protection Agency), Implementation Guidance for the Arsenic Rule, Environmental Protection Agency, Government Printing Office, Washington, D.C, 2002, pp. 6976-7066 (EPA-816-K-02-018).

[14] Sigdel A, Park J, Kwak H, Park PK. "Arsenic removal from aqueous solutions by adsorption onto hydrous iron oxideimpregnated alginate beads". Journal of Industrial and Engineering Chemistry, 35, 277-286, 2016.

[15] Zhao Y, Qiu W. "Arsenic oxidation and removal from flue gas using $\mathrm{H}_{2} \mathrm{O}_{2} / \mathrm{Na}_{2} \mathrm{~S}_{2} \mathrm{O}_{8}$ solution". Fuel Processing Technology, 167, 355-362, 2017.

[16] Lee CG, Alvarez PJJ, Nam A, Park SJ, Do T, Choi US, SangLee H. "Arsenic(V) removal using an amine-doped acrylic ion exchange fiber: Kinetic, equilibrium, and regeneration studies". Journal of Hazardous Materials, 325, 223-229, 2017.

[17] Abejón A, Garea A, Irabien A. "Arsenic removal from drinking water by reverse osmosis: Minimization of costs and energy consumption". Separation and Purification Technology, 144, 46-53, 2015.

[18] Katsoyiannis IA, Zouboulis AI. "Application of biological processes for the removal of arsenic from groundwaters". Water Research, 38(1), 17-26, 2004.

[19] Lacasa E, Canizares P, Saez C, Fernandez FJ, Rodrigo MA. "Removal of arsenic by iron and aluminium electrochemically assisted coagulation". Separation and Purification Technology, 79(1), 15-19, 2011.

[20] Kobya M, Demirbaș E, Cana OT, Bayramoğlu M. "Treatment of levafix orange textile dye solution by electrocoagulation". Journal of Hazardous Materials, 132(2-3), 183-188, 2006.

[21] Lakshmanan D, Clifford DA, Samanta G. "Comparative study of arsenic removal by iron using electrocoagulation and chemical coagulation". Water Research, 44(19), 5641-5652, 2010.

[23] Kumar PR, Chaudhari S, Khilar KC, Mahajan SP. "Removal of arsenic from water by electrocoagulation". Chemosphere, 55(9), 1245-52, 2004.

[24] Gomes JAG, Daida P, Kesmez M, WeirM, Moreno H, Parga JR, Irwin G, McWhinney H, Grady T, Peterson E, Cocke DL. "Arsenic removal by electrocoagulation using combined Al-Fe electrode system and characterization of products". Journal of Hazardous Materials, 139(2), 220-231, 2007. 
[25] Sık E, Kobya M, Demirbas E, Oncel MS, Goren AY. "Removal of As (V) from groundwater by a new electrocoagulation reactor using Fe ball anodes: Optimization of operating parameters". Desalination and Water Treatment, 56(5), 1177-1190, 2015.

[26] Kobya M, Ozyonar F, Demirbas E, Sik E, Oncel MS. "Arsenic removal from groundwater of Sivas-Şarkişla Plain, Turkey by electrocoagulation process: comparing with iron plate and ball electrodes". Journal of Environmental Chemical Engineering, 3(2), 1096-1106, 2015.

[27] Thakur LS, Prasenjit M. "Simultaneous arsenic and fluoride removal from synthetic and real groundwater by electrocoagulation process: parametric and cost evaluation". Journal of Environmental Management, 190, 102-112, 2017.

[28] Hansen HK, Nunez P, Raboy D, Schippacasse L, Grandon R. "Electrocoagulation in wastewater containing arsenic: comparing different process designs". Electrochimica Acta, 52(10), 3464-3470, 2007.

[29] Silva J, Mello JWV, Gasparon M, Abrahao WAP, Jong T. "Arsenate adsorption onto aluminium and iron (hydr) oxides as an alternative for water treatment". IMWA Symposium 2007: Water in Mining Environments, Cagliari, Italy, 27-31 May 2007.
[30] Kobya M, Ulu F, Oncel S, Demirbas E. "Removal of arsenic from drinking water by the electrocoagulation using $\mathrm{Fe}$ and $\mathrm{Al}$ electrodes". Electrochimica Acta, 56(14), 5060-5070, 2011.

[31] Kuokkanen V, Kuokkanen T, Ramo J, Lassi U. "Recent applications of electrocoagulation in treatment of water and wastewater-A review". Green and Sustainable Chemistry, 3(2), 89-121, 2013.

[32] Alcacio R, Nava JL, Carreno G, Elorza E, Martinez F. "Removal of arsenic from deep well by electrocoagulation in a continuous filter press reactor". Water Sciences Technology: Water Supply, 14(2), 189-195, 2014.

[33] Mohora E, Roncevic S, Dalmacija B, Agbaba J, Watson M, Karlovic E, Dalmacija M. "Removal of natural organic matter and arsenic from water by electrocoagulation/flotation continuous flow reactor". Journal of Hazardous Materials, 235-236, 257-264, 2012.

[34] Demirbas E, Kobya M, Oncel MS, Sık E, Goren AY. “Arsenite removal from groundwater in a batch electrocoagulation process: Optimization through response surface methodology". Separation Science and Technology, $53,1-11,2018$. 